\title{
Małgorzata Malec-Rawiński
}

\section{OLDER MEN'S BIOGRAPHICAL LEARNING AND MASCULINITY}

\begin{abstract}
The general aim of this paper is to present insights from a Polish case study on the learning experiences of Polish older men. The research data was collected by means of 'guided', semi-structured interviews. This paper presents two well-educated older men's life stories from two different local communities in Poland and the analyses of their life experiences in the context of masculinities and ageing using a biographical learning approach. The analyses of the two biographical narratives have shown the diversity in the life histories of older men, but also similar struggles and challenges. They have illustrated how older men cannot simply be reduced to their experience of ageing, but that they also carry some continuously (re)negotiated struggles with masculinity, weaving new and rich threads for learning that is lifelong and life-wide.
\end{abstract}

Keywords: biographical learning, masculinity, ageing, older men, life experiences

\section{BIOGRAFSKO UČENJE IN MOŠKOST PRI STAREJŠIH MOŠKIH - POVZETEK}

Namen prispevka je predstaviti poljsko študijo primerov o izkušnjah učenja starejših Poljakov. Podatki so bili zbrani s pomočjo delno strukturiranih vodenih intervjujev. Prispevek se osredotoča na življenjski zgodbi dveh izobraženih starejših moških iz različnih lokalnih skupnosti na Poljskem in analizi njunih življenjskih izkušenj v okviru moškosti in staranja z uporabo pristopa biografskega učenja. Analizi obeh biografskih pripovedi sta pokazali na raznolikost življenjskih zgodovin starejših moških, hkrati pa tudi na soočanje s podobnimi napori in izzivi. Pripovedi sta ponazorili, da starejših moških ne moremo preprosto enačiti z njihovo izkušnjo staranja, ampak da nosijo tudi nekaj stalnega (pre)pogajanja z moškostjo ter spletajo nove in bogate niti tako za vseživljenjsko kot večrazsežnostno učenje.

Ključne besede: biografsko učenje, moškost, staranje, starejši moški, življenjske izkušnje 


\section{INTRODUCTION}

In European studies, the issue of masculinity attracts less attention than its counterpart, femininity. However, knowledge about men's learning (especially older men), well-being, activity or interests is presented in some publications. The few exceptions in Anglophone literature demonstrate the propensity for learning among older men to have a positive influence on their well-being, for example, the significant research on men's lives by the Harvard Study of Adult Development ${ }^{1}$. This longitudinal research project of adult health and well-being, which began in 1938, has closely examined the lives of more than 700 men and in some cases their spouses (Vaillant, 2012). Other international research on men's informal learning has shown that informal learning - for example, Men's Sheds ${ }^{2}$ - can have a significant, positive impact on their lives. In Australia, research has shown that enriching learning among older men can make a difference to several dimensions of their lives, positively affecting their well-being (Golding, 2011; 2015a; 2015b). Further research has demonstrated that "men tend to choose hands-on activities, more problem-oriented activities and practical involvement where they can talk 'shoulder to shoulder', rather than being involved in indoor settings where most of the activity is face to face" (Formosa, Fragoso, \& Jelenc Krašovec, 2014, p. 24).

Fewer studies on the learning activities of older men exist in our case study area, Poland. In Poland, older men are less visible in formalised educational activities offered by organisations such as Universities of the Third Age and/or Senior Clubs. Researchers are relatively less interested in studying the participation of older men in learning activities. Men are typically more visible in political parties, sports clubs, local government authorities and circles of interest concerning sports, hunting, motoring or fishing. In villages, towns and cities, if older men are active at all, their activities tend to continue in line with skills they had already developed. Yet Men's Sheds have also been established in Poland, with one in each of the cities of Warsaw, Słupsk and Wrocław.

This article is based on the data collected as part of the Erasmus+ project Old Guys Say Yes to Community (KA2-AE-9/16) ${ }^{3}$. The project centred around cooperation for innovation and the exchange of good practices. Its aim was to foster the inclusion of older men, aged 60 years or more, and especially those with a low level of education, in learning and education activities with the view to positively affect their well-being, health, social life and to contribute to their re/upskilling. Each research partner interviewed a sample of 90 to100 men in their respective communities.

1 The Harvard Study of Adult Development https://www.adultdevelopmentstudy.org/.

2 A huge social movement of Men's Sheds exists mostly in Australia and New Zealand; however, a similar movement is growing in some European countries as well, e.g. Ireland, England, Denmark, Sweden, Poland.

3 Research was conducted by four research partners from Slovenia, Estonia, Portugal and Poland (2016-2019). 
The aim of this paper, then, is to present insights from the Polish case study on the learning experiences of Polish older men. I take a biographical learning perspective in considering how these men position the meaning of life from an ageing perspective and in the context of their masculinity. The research questions specific to this paper were: How do the older men's life experiences and their masculinity shape their biographical learning? What is important for older men from an individual and ageing perspective? What is the meaning of their lives? What is expected of 'being a man' from a biographical perspective?

\section{MASCULINITIES IN THE CONTEXT OF AGEING}

As we age, we become (more) invisible and even 'genderless'. Older adults often experience internal struggles about health, isolation, loneliness, lack of duties, money and sometimes about gender. Moreover, they are also often portrayed as 'the others', as unproductive and problematic for society. In general, women face more social and economic disadvantages than men in this ageing process. However, men are not always the clear 'winners' - quite often they suffer more ill-health than women (Cleaver, 2002) and there are some social, cultural and educational aspects that differ between the genders (Kogan, 2016).

It is also important to consider that ageing is not uniformly experienced across the spectrum of one gender - there is not one pattern of masculinity. As Connell (1995) has argued, the concept of masculinity or male dominance is played out or has been recognised in various ways, from hegemonic dominance to subordinate or less powerful configurations of masculine practices such as those of subordinate masculinities. There is not one pattern of masculinity. Hegemonic masculinity is represented by specific, idealised stereotypes about what it means to 'be a man', and it refers to male norms that are considered ideal and dominant over other forms of masculinity in a given place and time (Connell, 1995). In different cultures, the social positions of genders differ. Considering masculinity in the context of ageing, I argue that the pattern of older men's masculinity is as diverse as their life experiences and is connected with cultural, historical, educational and social background. Different generations have historically, socially and culturally specific gender identities shaped by changes in the relationships between men and women that affect the dynamic nature of gender (Calasanti, 2004). Thus, older women might be perceived differently to older men in some societies. For example, women often ask for help more frequently and seek care more often than men, and these actions increase their visibility in many social and educational forums. The higher quantum of scholarship on older women may come as a result of such activities.

In the case of Polish society, there are two overlapping paradigms of masculinities. The first, a traditional one, conceives of masculinities as dominating, aggressive and specialised. The second paradigm emerges from the postmodernist perspective, which maintains that the characteristics of the 'new/modern' man are cooperative rather than dominant and capable of expressing emotions and desires (Chmura-Rutkowska \& Ostrouch, 2007). 
Men whose characteristics fall outside these two paradigms include disabled, homosexual, transgender, and older men, including those with lower levels of formal education.

\section{THE BIOGRAPHICAL APPROACH AS THE RESEARCH FRAMEWORK}

Ageing is a significant resource through which individuals construct their biographical narratives across the life course, both in terms of the past, looking back from old age, and looking forward (Hockey \& James, 2003). While we are ageing, we more often wonder: What is important in our lives? Who are we? What do we have? What are we longing for or missing? Undertaking life histories is one way to gain insight into the experiences of individuals. Yet such stories are never isolated products; in fact, there are close links between the story and other social, cultural and ideological contexts. 'Life construction', therefore, is generated between the twin poles of structure and subjectivity (Alheit, 2009) and is an ongoing forming process of a person's life. In this research, I used the biographical approach (Alheit, 1995; 2009; Alheit \& Dausien, 2002; Bron, 2000; 2007; Bron \& West, 2000; Dominicé, 2000) to investigate older men's life experiences and the ageing process in the context of masculinities. I adopted a learning perspective to better understand learning as a part of life that requires people to face a whole variety of different experiences. The biographical approach used here aligns closely with learning and is embedded within societal structures and cultural contexts of interpretation (Alheit \& Dausien, 2002). It takes into account an individual life in its entirety, in all its phases, as a framework for potential learning. Referring to the concept of 'unlived life' (Alheit, 1995), by reflecting on their own biographies, individuals can: create new meanings for the processes of their lives; ascribe/imply meanings to events and experiences of the past, to ongoing events and experiences, as well as to ideas and dreams of the future (Malec-Rawiński, 2017). Alheit (1995) has used the term 'biographicity' to explain how adults construct and reconstruct their lives as a way to understand one's own life construction.

Life course and ageing are like an unpredictable flow of a river (Hockey \& James, 2003). Listening to older men's life stories, we find "a strange combination of power and powerlessness, privilege and pain" (Kaufman, 1994, p. 144), happiness, love, illnesses and death as well. Such knowledge can help us understand the differences between men's lives, their happiness, sense of power or powerlessness, their vulnerabilities, needs, desires, problems and struggles. Yet "not all individuals pass through the same set of stages" (Schuller, 1992, p. 19). In telling a life story, a person can reflect on their unique life, struggles, life crises, and can give their life meaning. This reflection can lead to reflexive learning, which might change people's perspectives and thus have transformative capacities (Bron, 2007). The reflective learning process occurs in tandem with communication and interaction with others and in relation to the social and cultural context (Alheit, 2009).

The Polish team, researchers and students from the University of Wrocław, conducted 99 interviews with older men in selected municipalities in Poland: the municipality of Turek - Żuki, the Brzeg municipality, the Jędrzejów community, the Sobótka community, and 
the Żmigród community. The different conditions and opportunities in each community created multiple options for initiatives offered to older men. The research data was collected by means of 'guided', semi-structured interviews. The interview format constructed by the team and adopted in the national case studies meant that there was consistency in the questions and also, if necessary, flexibility according to the local conditions. The interviews differed in length. Some of the participants told their life stories while others simply answered questions from guided interviews; some were well-educated men and the others had received a lower level of education. The sample represents a mixture of men with different social, educational and cultural backgrounds. What follows is the analyses of two well-educated older men's life stories.

\section{ANALYSES OF TWO BIOGRAPHICAL NARRATIVES}

In the following section, I present two biographical narratives from older men in two local communities in Poland: Sobótka (Lower Silesia) and Jędrzejów (in the central part of the country). First, I present Jan's and Mark's vignettes, followed by the analyses of their life experiences in the context of masculinities and ageing using a biographical learning approach. Finally, I present a discussion of the findings and the conclusions.

\section{Jan's vignette}

Jan is 72 years old and lives in the small local community of Sobótka in the Lower Silesia region, which is around 50 kilometres from Wrocław. He is a former primary school teacher (his educational background is in music) and used to work as a tutor with children and teenagers with special needs. He enjoyed his job but because he felt burnt out, he decided to take the advantage of earlier retirement after 30 years of work. However, when he retired, he continued to work but not in his profession. He used to work as a greengrocer, an insurance salesman, a pottery salesman and as a tiler. He considered these occupations as something new and as a challenge. He is proud of his two adult daughters, mostly because he contributed to their education. He is happy with his family even if he longs for grandchildren (he likes children very much). His wife's health is deteriorating, and this worries him a lot. Family is important to him, not just his immediate family but his brothers as well. He used to have a dog that helped him stay fit and active and gave structure to his everyday life. Since the dog has been gone, he has considered getting a new one. Music is his big passion. He has been interested in music his entire life. After his retirement he started to learn to play various instruments. He likes to play an instrument every day and this makes him happy. He used to lead a music band of men from his local community. Another of his hobbies is mountain climbing. He loves to hike in the mountains with a group of friends, who arrange mountain excursions every year. He is satisfied with his life.

\section{Mark's vignette}

Mark is 73 years old. He lives in the small local community of Jedrzejów where he settled after he completed his education in Poznań. He is a former academic teacher. He received 
his $\mathrm{PhD}$ in Chemical Wood Technology at the Agricultural Academy in Poznan, where he held the position of lecturer. He was satisfied as an academic teacher and researcher. The students liked him and because of his research, he used to attend many conferences in Poland and abroad. He worked in this position until he was 60 years old (in Poland, it was possible to retire at 60 up until a few years ago). He is interested in astronomy and fascinated by ancient history; he reads a lot of books on both topics. Following his retirement, he discovered an interest in water towers that are now considered historical monuments. He has travelled around Poland taking pictures of them and even started to write short stories about the water towers. However, his wife said that this topic was "nothing of interest", so he gave up his writing. He has a big family, a wife, four daughters and ten grandchildren. After he gave up his water tower project, he felt lost somehow. He did, however, realise how occupied his wife was by their grandchildren, so he began helping her with their care. Six years into his retirement he decided to 'repair' his budget: he found a job as a warden in a courthouse. He has also been interested in discovering his family's roots and is writing a book on his family history. He has been diagnosed with cancer but doesn't want to make a big issue out of it. He treats the cancer as 'the tenant' that gnaws at him bit by bit.

\section{Analysis}

For data analysis, a grounded theory approach was used (Glaser, 1992; 1995). Grounded theory requires a careful and discrete sequence of analysis: open coding, selective coding, discovery and naming categories (Glaser, 1992). The analyses of Jan's and Mark's life stories showed some similarities as well as differences in accordance with the biographical patchwork of their life experiences. The emergent themes were coded and named as the following categories: accepting ageing/life; following the goals of life; dealing with life crises; coping with retirement; struggling with being a man; enjoying hobbies and having pets; taking care of health; and building relationships (family/friends). After establishing these themes, I worked out how each theme was embodied in Jan's and Mark's life stories. As the coding progressed, some categories began to overlap or connect with each other, which led me to rationalise my initial list into four categories: accepting ageing/life and following life goals; dealing with life crises in the context of retirement; enjoying hobbies and having pets; and self-care and care for significant others.

\section{ACCEPTING AGEING/LIFE - FOLLOWING THE GOALS OF LIFE}

Both men reflected upon their lives and came to similar conclusions regarding the acceptance of life/ageing. Neither regretted their lives so far, either how they lived, accepting the past and the present, or the ageing process itself. As Jan said:

I was born in such times and did what I did, I did it honestly, for money, and as well as I could and... for me, old age is neither good nor bad, I know this is the one and only direction for everybody... 
Similarly, Mark stated the following: "if I had the choice, I would live my life the same way, the only difference is that I would spend more time with my family". From a biographical perspective and ageing as a learning process, Mark said:

I am an old man... my life is almost over but I have had some experience of good and bad. I rarely met bad people; most people are good and nice. I am seeing things from the perspective of an old man.

Mark's comments are emblematic of the fact that when we are young, we do not think about the process of ageing that is already underway. In that vein, Jan also commented: "everyone is young but if she/he grows older, it is uncertain". Both Mark and Jan share advice for a good life, one that could enhance learning to enrich life and accept the ageing process. Mark said: "after years I have discovered that people should practice living with a sense of humour... it should be a skill to break the everyday tensions". Jan stated: "in every stage of life, you have to define what you want from life, from yourself, from the environment and place yourself in this life". In these comments, both men reveal that we need to learn how to approach the life course with a sense of humour and by following our life goals. This approach has helped them and could help us understand ageing as an ongoing process at any stage of life.

\section{DEALING WITH LIFE CRISES IN THE CONTEXT OF RETIREMENT}

Work was an important part of life for both men. They coped with retirement differently, notwithstanding that they both felt burnt out at the end of their working lives. Mark had worked in one place his entire life but was very satisfied with his job as it had given him a kind of independence. However, he cautioned: "I was working so hard with no holidays for years because I did not want to rest", and he was "simply burnt out" as his boss demanded he take his unused vacation days. Working as an academic, Mark travelled frequently, making friends abroad. He said that "academic work and work with students gave [him] a minimum of independence and some kind of freedom". Nevertheless, "retirement was a serious trauma" for Mark because he has lost his sense of feeling needed. He faced a "life crisis" and in trying to deal with it, took up a new hobby but gave that up too. It was then that the "emptiness began". He asked:

Why am I here? There is no use for me[.][...] The grandchildren began growing up. My wife started helping them, and so I switched to grandchildren and started helping them.

When Mark decided to "make his budget more flexible", this financial motivation was also guided by a desire to "be more socially useful" - he started working as a guard in a courthouse. This new job shocked his family. Their comments ("You? An academic teacher/researcher as a guard?", and from his favourite granddaughter, "Grandpa, so you are the jailor?") hurt him and he struggled to finding positive ground once again. 
Indeed, his attempts to find the positive aspects of the guard job demonstrate his attempts to try and overcome the apparent degradation in social status. As a well-educated man with a $\mathrm{PhD}$, this 'new' position/social status brought his masculinity into question.

Jan had changed jobs many times in his working life. He had been a tutor for children with special needs, but after retirement, he pursued many different jobs not related to his previous profession, for example, greengrocer, insurance salesman, pottery salesman, and tiler. Jan thinks of these jobs as a "time of soft transition [when he] wanted to do something different, something completely different... but [he always] had a plan". Jan enjoyed these jobs even though they were below his qualifications. He just kept himself busy until he became bored. After retirement, he came back to music, as his first role was that of a music teacher. Although Jan went through some transitions in his life, he seemed to treat any difficulties as challenges, and he faced them smoothly and without excessive questioning.

\section{ENJOYING HOBBIES AND HAVING PETS}

Hobbies are an important part of life. They are a kind of engine that provides sustenance for life. After retirement, hobbies become more valuable for men because they have more free time. Jan's biography shows how music, for example, was essential to him. He noted that:

music fulfil[s] me... making music in old age is the best thing for your memory, to exercise your memory and to avoid dementia... in old age, a man could have no reason to exist, could not accept himself, and music helps [him] to not fall into nothingness.

The dream of buying another instrument makes him happy. He claims that buying another violin is a better investment than buying a new car: "[a] car bought today will be worth less tomorrow. My violin bought today will be worth double tomorrow or in the future". Indeed, Jan plays music every day for pleasure. His hobby, because of his role as a band leader, has enhanced other men's learning too. In addition to music, Jan's second passion are the mountains: "I love hiking in the mountains". Reaching another peak and being with friends has enriched his life. These hobbies have not only brought him enjoyment but have also kept him learning and enhancing his well-being.

Hobbies may be shared with others or practiced alone, as in Mark's case. He is a passionate reader of astronomy and ancient history: in his opinion, both topics are "an absolute hit", and an opportunity to deduce "how events affect the fate of humanity". Studying, exploring and discovering new facts have enabled him to reflect upon the world. However, such reflection also posed a risk to this passion when it was shared with others. For example, after retirement, Mark discovered a new interest: 
I can take a photo of water towers and write short stories. The water towers are historical monuments... so they are under protection... I'll fill my time for many years... I gave a few of these stories to my wife to read and review. She said: 'Come on! You are not a humanist!'... I gave up after few years... Emptiness appeared.

It seemed important to Mark that someone reinforced and approved of his hobby. If we do what we like, what makes us happy, we get energy and power for life. We learn to accept life/ ageing and do not need to question who we are as a human being or as a man/woman so often.

The analysis of Jan's life stories shows that having a pet structured the rhythm of his day and helped maintain a level of physical activity. Pets provide companionship and someone to talk to, to walk with and someone who waits for you. When pet owners get older, they do not feel lonely. The analysis of Jan's experiences as a dog owner showed it to be a good solution for physical, social and mental health.

\section{TAKING CARE OF YOUR HEALTH AND THE HEALTH OF SIGNIFICANT OTHERS}

Both men's biographies reveal the importance their wives' health have for their own well-being. For example, Jan feels good and that he should not complain about his health because he is "worr[ied for his] wife's health, she is suffering," resulting in a "lack of contact with her". Mark is not healthy (he has cancer) but he does not want to talk about it much. Mark used to work a lot; he notes: "I came home only to sleep; my whole life was spent at work". As he reflected upon his life, he reasoned that he should have spent "more time with [his] family." It provided him with insight into who and what was and should have been important for him. He also now referred more to the health of his wife: "she was working very hard. She brought up four kids... I have a guilty conscience... She is exhausted [and] now she is more disabled... She devoted everything to the family". The health of significant others (wives, children, siblings, and friends) influenced the men's own well-being, and the way they have handled their own health problems. Building and taking care of relationships with their family members appeared to be fundamental to both men.

\section{THE OUTCOME OF THE ANALYSES}

From both men's biographies, I developed a schematic of older men's biographical learning (see Figure 1). The patchwork of the men's life experiences - an acceptance of ageing/ life, following the goals of life, dealing with life crises, coping with retirement, struggling with being a man, enjoying hobbies and having pets, taking care of your health, building relationships - shaped their ongoing learning process in accordance with their experiences. The 'core category' that emerged from the analysis is related to the struggles associated with 'being a man'. Masculinity was identifiable in some coded themes, for example, dealing with life crises, coping with retirement, enjoying hobbies, having pets and taking care of their health. Yet many of the identified struggles of being a man were not individual but rather socially and culturally (re)constructed. Dealing with masculinity 
involved the interaction and struggle with and between institutional structures and societal conditions, including cultural and social backgrounds and how these shaped the older men's lived experiences, activities and interpretations of their biographies (Alheit, 2018).

Figure 1: The formation of older men's biographical learning

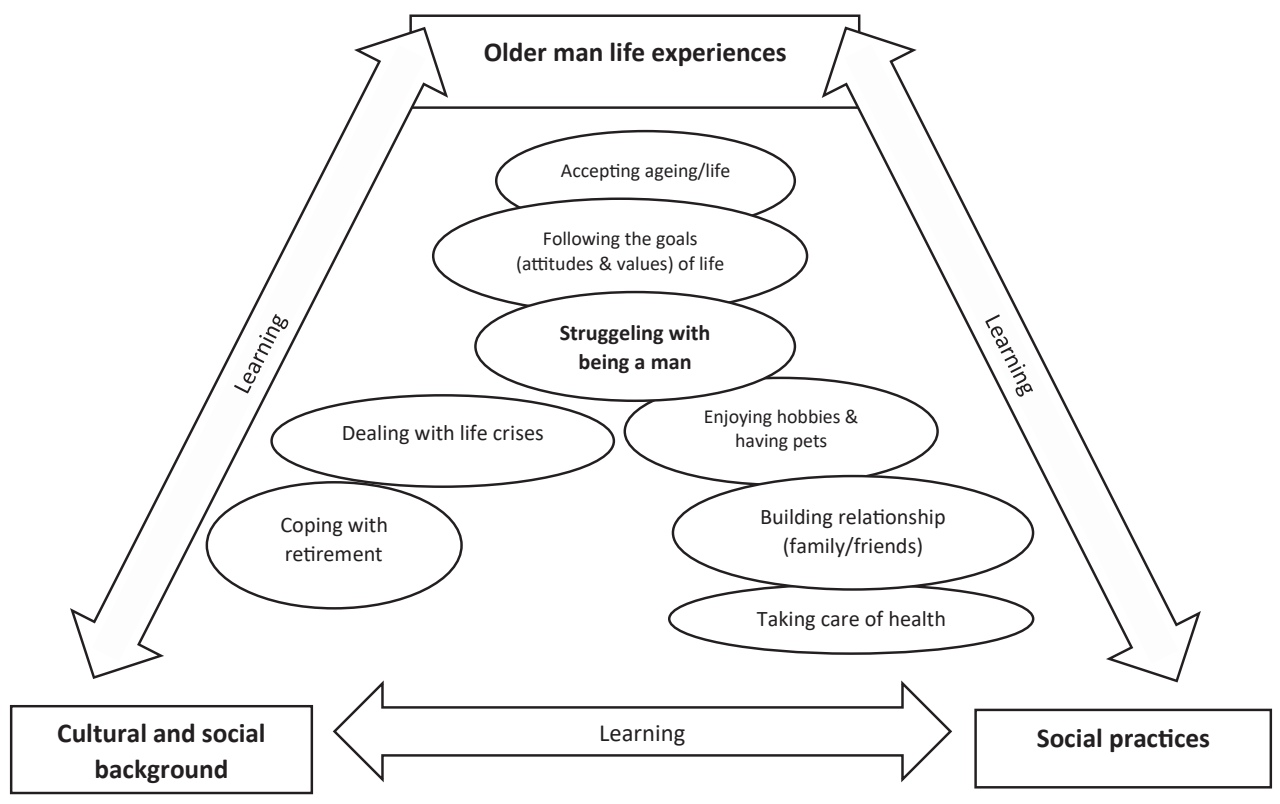

Source: Created by the author.

Each man's biographical learning has been unique and fluid and has been influenced by a pastiche of their life experiences.

\section{DISCUSSION AND CONCLUSIONS}

In the schematic, I created the triangular shape to understand the intersections of older men's ongoing learning with their backgrounds and social practices. I am drawing on Tom Schuller's ${ }^{4}$ triangular conceptualisation of the wider benefits of learning, where learning is positioned as

a process whereby people build up - consciously or not - their assets in the shape of human, social or identity capital, and then benefit from the returns on the investment in the shape of better health, stronger social networks, enhanced family life (Schuller et al., 2004, pp. 12-13).

4 Tom Schuller was the leader of project team whose aim was to "take a step forward along to the path towards a clearer understanding of how learning affects people lives" (Schuller et al., 2004, p. 4). 
As this analysis has shown, men constantly construct and reconstruct their life in relation to their life experiences and interactions with specific environments. From a biographical perspective, ageing is a learning process: people (re)construct their lives, social, educational and cultural contexts, and draw from their experiences relating to social practices in those spaces. Each man has an individual ongoing biography. They build up a biographical plan of everyday actions to deal with external structure and objective facts, life's struggles (crises and successes), hobbies, emotions, habits and values. While dealing with life crises, spurred in these two examples by retirement, the struggles of being a man therefore also relate to constructions of masculinity. The clash between the two models of masculinity - traditional and modern - was visible in both biographical interviews. I argue that the socio-cultural contexts and social practices/interactions with family members reflect through life experiences and are of the utmost importance when it comes to articulations and performances of masculinity.

Mark's masculinity was put into question by his family members. In both his professional and private life, Mark has struggled with the two paradigms of masculinities. He grew up being a young researcher and lecturer, a husband and a father in a society dominated by the traditional paradigm of masculinity. As the head of his family, he worked hard to become a successful researcher and academic, and thus he anchored himself to his work. Being afraid of retirement, he found a new hobby - taking photos of water towers. When he gave this up, he noticed that the "emptiness appeared" - he experienced what is called 'floating'. Bron (2000) has described floating as a deep feeling of being paralysed by events, circumstances or experiences, where a person cannot deal with the psychological, emotional and social aspects of their lives. The person might feel overwhelmed without any idea of what to do; this is how Mark felt. He struggled with his needs, desires, problems and the external expectations that his family had of him. "People have different expectations that sometimes are too difficult to meet, and they struggle to fulfil them as well as their wishes and dreams" (Bron \& Thunborg, 2017, p. 124). Such expectations led Mark to feelings of misplacement as a husband, father, grandfather and worker; they impacted his identity as a man.

Jan seemed to align mostly with the characteristics of the 'modern' man, while struggling with the invisibility aspects of the traditional paradigm of 'being a man'. The changes in his life went quite smoothly, with music helping him. His two big passions - music and mountains - anchored him to 'his place in life'. The findings of the Older men, music and well-being ${ }^{5}$ project show that music is an integral part of men's lives. It is much more than just an activity: men described music as a part of their identity:

It helps them to regulate their moods, makes them relax or cheer up and helps them to be in touch with and to develop their emotional lives. Music also facilitates the creation of social bounds, and strengthens these men's relationships (Lindbland, 2018, p. 103). 
Jan shared his hobbies with others, both when it comes to his band and his climbing. He seemed to have very deep relationships with his wife and daughters, noting that "family is the most important thing in [his] life". In Jan's biography, I identified findings parallel to the results of the Harvard Study of Adult Development ${ }^{6}$ (Vaillant, 2012). That research suggested that one of the most important predictors of whether you age well and live a long and happy life is not the amount of money you amass or the notoriety you receive, but that the relationships with friends, and especially spouses, are core (O'Connor, 2016). The Harvard study also showed that people who had the strongest relationships were protected against chronic disease, mental illness and memory decline - even if those relationships had many ups and downs. The number of relationships does not matter as much as their quality (ibid.). Thus, perhaps the quality of relationships matters to masculinity too? Being accepted as a husband, a father, a friend, a leader of a band can engender the feeling of equality and satisfaction with life, and in turn perhaps the issues of masculinity become less important. "Biographical work is visualised as a process in which identity struggles give way to processes of floating, i.e. feelings of being fragmented without past or present, and anchoring, i.e. feelings of belonging to a specific context or grounded in oneself" (Bron \& Thunborg, 2017 , p. 122). The process of identity formation and transformation of older men is visible in at least two dimensions: ageing and masculinity. Ageing is a learning process, with ups and downs, related to life experiences that these two men accepted. Yet more complex and difficult to handle was being men, their masculinity. Although the pattern of older men's masculinity is as different as their life experiences, it remains connected with their cultural and social background, and related to their connection with others. As Alheit has claimed, "the learning processes take place 'between' subjects and the worlds relevant to them - and these worlds change and are themselves historically variable" (2018, p. 14). The world the men live in is changing, which effects the dynamic nature of gender performances. Being a man or a woman today is different to their articulations in the past, and as I have argued in previous research, ageing is a challenge both for individuals and for society (Malec, 2012; Malec-Rawiński, 2014; 2016; 2017). I would add that it is also challenging across genders.

This explorative study of men's ageing and their biographical learning necessitates further research. What these case studies have shown is the diversity in the life histories of older men, but also certain similar struggles and challenges. The research has illustrated how older men cannot simply be reduced to their experience of ageing, but that they also carry some continuously (re)negotiated struggles with masculinity, weaving new and rich threads for learning that are both lifelong and life-wide.

6 Harvard Study of Adult Development, https://www.adultdevelopmentstudy.org/. 


\section{REFERENCES}

Alheit, P. (1995). Biographical learning: Theoretical outline, challenges and contradictions of a new approach in adult education. In P. Alheit, A. Bron-Wojciechowska, E. Brugger \& P. Dominicé (Eds.), The biographical approach in European adult education (pp. 57-74). Vienna: Verband Wiener Volksbildung.

Alheit, P. (2005). Stories and structures: An essay on historical times, narratives and their hidden impact on adult learning. Studies in the Education of Adults, 37(2), 201-212.

Alheit, P. (2009). Biographical learning within the new lifelong learning discourse. In K. Illeris (Ed.), Contemporary theories of learning: Learning theorists... In their own words (pp. 116-128). London: Routledge.

Alheit, P. (2018). The concept of 'biographicity' as background theory of lifelong learning? Dyskursy Młodych Andragogów, 19, 9-22.

Alheit, P., \& Dausien, B. (2002). The double face of lifelong learning: Two analytical perspectives on a silent revolution. Studies in the Education of Adults, 34(1), 3-22.

Bennett, K. M. (2007). No sissy stuff: Towards a theory of masculinity and emotional expression in older widowed men. Journal of Ageing Studies, 21, 347-356.

Błędowski P., Szatur-Jaworska B., Szweda -Lewandowska Z., \& Kubicki P. (2012). Raport na temat sytuacji osób starszych w Polsce. Warszawa: IPSS. Retrieved from http://senior.gov.pl/source/ raport_osoby\%20starsze.pdf.

Bron, A. (2000). Floating as an analytical category in the narratives of Polish immigrants to Sweden. In A. Nils Uggla (Ed.), Allvarlig debatt and rolig lek (pp. 119-132). Uppsala: Uppsala Universitet, Centrum för Multietnisk Forskning.

Bron, A. (2007). Learning, language and transition. In L. West et al. (Eds.), Using biographical and life history approaches in the study of adult and lifelong learning: Perspectives from across Europe (pp. 205-220). Frankfurt: Peter Lang.

Bron, A., \& West, L. (2000). Time for stories: The emergence of life history methods in the social sciences. International Journal of Contemporary Sociology, 37(2), 158-175.

Bron, A., \& Thunborg, C. (2017). Theorising biographical work from non-traditional students' stories in Higher Education. International Journal of Contemporary Sociology, 54(2), 112-127.

Calasanti, T. (2004). Feminist gerontology and old men. Journal of Gerontology, 59B, 305-314.

Chmura-Rutkowska, I., \& Ostrouch, J. (2007). Mężczyźni na przetęczy życia. Studium socjopedagogiczne. Kraków: Impuls.

Cleaver F. (2002). Men and Masculinities: New Directions in Gender and Development. In F. Cleaver (Ed.), Masculinities Matter! Men, Gender and Development (pp. 1-25). London, New York: Zed Books.

Connell, R. W. (1995). Masculinities. Cambridge: Polity Press.

Dominicé, P. (2000). Learning from our lives: Using educational biographies with adults. San Francisco: Jossey-Bass.

Formosa, M., Fragoso, A., \& Jelenc Krašovec, S. (2014). Learning across Generations in Europe. Contemporary Issues in Older Adult Education. Rotterdam: Sense.

Glaser, B. G. (1992). Basics of grounded theory analysis. Mill Valley: Sociology Press.

Glaser, B. G. (1995). Doing grounded theory: Issues and discussions. Mill Valley: Sociology Press.

Golding, B. (2011). Older Men's Wellbeing Through Community Participation in Australia. International Journal of Men's Health, 10(1), 26-44.

Golding, B. (2015a). Men Learning Through Life (and Men's Sheds). Adult Learning, 26(4), 170-172. 
Golding, B. (Ed.) (2015b). The Men's Shed Movement: The Company of Men. Champaign: Common Ground Publishing.

Harvard Study of Adult Development. (2015). Retrieved from https://www.adultdevelopmentstudy.org.

Hockey, J., \& James, A. (2003). Social identities across the life course. New York: Palgrave.

Kaufman, M. (1994). Men, Feminism, and Men's Contradictory Experiences of Power. In H. Brod \& M. Kaufman, Theorizing Masculinities (pp. 142-164). Thousand Oaks: Sage.

Kogan, L. (2016). Older Adults and Pets - Physical and Psychological Benefits. In C. Blazina \& L. R. Kogan (Eds.), Men and Their Dogs (pp. 257-280). Cham: Springer.

Lindbland, K. (2018). Music as the promotor of well-being for older men. In E. Kristoffersson, K. Nilsson \& K. Lindbland (Eds.), Successful ageing in an interdisciplatory context - popular science presentations (pp. 98-106). Örebro: Örebro University.

Mackenzie, C., Robertson, S., \& Nurmi, M. (2017). Counter and Complicit Masculine Discourse Among Men's Shed members. American Journal of Men's Health, 11(4), 1224-1236.

Malec, M. (2012). Learning in later life and the construction of meaning: Biographical research and the 'signposts of life'. International Journal of Education and Ageing, 2(3), 197-210.

Malec-Rawiński, M. (2014). Fenomen długowieczności i starzenia się z perspektywy auto/biograficznej. Rocznik Andragogiczny, 21, 283-295.

Malec-Rawiński, M. (2016). Longevity and learning from the biographical perspective: Two case studies - locally rooted and globally oriented. Andragoška spoznanja, 1, 43-56.

Malec-Rawiński, M. (2017). Ageing and learning experiences: The perspective of a Polish senior immigrant in Sweden. Australian Journal of Adult Learning, 57(3), 421-439.

O'Connor, A. (2016). The Secrets to a Happy Life, From a Harvard Study. Retrieved from https://well. blogs.nytimes.com/2016/03/23/the-secrets-to-a-happy-life-from-a-harvard-study/?_r=0.

Sandberg, L. (2011). Getting intimate: A feminist analysis of old age, masculinity and sexuality. Linköping: Linköping Studies in Arts and Sciences.

Schmidt-Hertha, B., Jelenc Krasovec, S., \& Formosa, M. (Eds.) (2014). Learning across generations: Contemporary issues in older adult education. Rotterdam: Sense.

Schuller, T., Preston J., Bynner, J. M, Hammond, C., \& Brassett-Grundy, A. (2004). The Benefits of LearningThe Impact of Education on Health, Family Life and Social Capital. London, New York: Taylor.

Schuller, T. (1992). Age, gender, and learning in the lifespan. In A. Tuijnman \& A. van der Kamp (Eds.), Learning across the lifespan: Theories, research, policies (pp. 17-32). Oxford: Pergamon Press.

Vaillant, G. E. (2012). Triumphs of Experience. The Men of the Harvard Grant Study. Cambridge: Harvard University Press. 